\title{
Effect of Plant Derived Smoke on Germination and Post Germination Expression of Wheat (Triticum aestivum L.)
} \author{
Sumera Shabir'1, Muhammad Nasim Ashraf Faz ${ }^{2}$, Abdul Rauf ${ }^{3}$ \\ ${ }^{1}$ Department of Botany, PMAS-Arid Agriculture University, Rawalpindi, Pakistan \\ ${ }^{2}$ Department of Botany, Government College University, Faisalabad, Pakistan \\ ${ }^{3}$ Department of Biology, AIOU, Islamabad, Pakistan \\ Email: *mmiqballali@gmail.com
}

Muhammad Iqbal ${ }^{*}$, Saira Asif ${ }^{1}$, Noshin Ilyas ${ }^{1}$, Naveed Iqbal Raja1, Mubashir Hussain ${ }^{1}$

Received 14 March 2016; accepted 18 April 2016; published 21 April 2016

Copyright (C) 2016 by authors and Scientific Research Publishing Inc.

This work is licensed under the Creative Commons Attribution International License (CC BY).

http://creativecommons.org/licenses/by/4.0/

(c) (i) Open Access

\begin{abstract}
Smoke produced from burning of plant material elicits a striking increase in seed germination in various plant species. In present work, effect of plant derived smoke exposure on wheat (Triticum aestivum L.) seeds germination and post germination response has been studied in laboratory. Plant derived smoke was generated by burning of plant material (leaf, straws etc.) in a special designed furnace. Non-imbibed and imbibed seeds of wheat were exposed to plant derived smoke for $1 \mathrm{hr}$ time duration. Best results were observed in non-imbibed seeds treated with plant derived smoke while imbibed seeds showed poor response to germination percentage, germination index, seedling vigor index and root shoot length. It has been proved from present study that plant derived smoke has stimulatory effect on germination \& post germination response of non-imbibed seeds while it may cause inhibitory effect in imbibed seeds of wheat.
\end{abstract}

\section{Keywords}

Plant Derived Smoke, Wheat, Seed Germination, Seedling Vigor, Root Shoot Length

\section{Introduction}

Wheat (Triticum aestivum L.) is an annual, self-pollinated, long-day cereal crop, and it is one of the most im-

*Corresponding author.

How to cite this paper: Iqbal, M., Asif, S., Ilyas, N., Raja, N.I., Hussain, M., Shabir, S., Faz, M.N.A. and Rauf, A. (2016) Effect of Plant Derived Smoke on Germination and Post Germination Expression of Wheat (Triticum aestivum L.). American Journal of Plant Sciences, 7, 806-813. http://dx.doi.org/10.4236/ajps.2016.76075 
portant food items in Pakistan as well as in the world. Pakistan is among the 9th largest wheat growing countries of the world accounting $3.04 \%$ of the world's wheat production from an area of $3.57 \%$ of the world [1]. Approximately 600 million metric tons of wheat are commercially milled annually and consumed in nearly every nation of the world [2]. Wheat has always been subjected to extensive and ceaseless research so as to maximize grain production but also to improve grain yield per unit area. However, still considerable gap exists for improvement, especially to amplify efforts for continued yield improvement of wheat to meet the growing requirements of an ever increasing population. In this context, great potential is embodied in the recent discovery of plant derived smoke for promoting seed germination and enhancing plant growth [3]. Plant derived smoke play a positive role in enhancing seed germination of many hard-to-germinate and rare and threatened species [4]. Plant derived smoke has been also shown enhancing seed germination, seedling growth and vigor of a wide range of agricultural and horticultural crops [5]-[8]. One pre-requisite for the application of plant derived smoke for enhancing seed germination and seedling growth is the use of smoke must be purely obtained from burning of plant material. This technology is a good substitute to traditional agricultural practices applied to enhance seed germination and plant growth in different plants and crops as it is of low cost, easily approachable and of more useful method to obtained high yield. There is also a great scope for application of this plant derived smoke for enhancing seed germination and plant growth in many important commercial crops like wheat. The main objective of this work was to quantify the possible effect of plant derived smoke on wheat seed germination and early growth stages (post germination).

\section{Materials and Methods}

\subsection{Plant Material Collection and Production of Plant Derived Aerosol Smoke}

Plant material (leaf, straws etc.) were collected from the outskirts of PMAS-AAUR Rawalpindi, Pakistan. Aerosol smoke was produced by burning of semi dried plant material in a specially designed furnace and aerosol smoke was collected for further process.

\subsection{Seeds Source}

Seeds of wheat (Triticum aestivum L.) varieties NARC-2011, Aas-2011, Pakistan-2013 and Glaxy-2013 were taken from National Agriculture Research Institute (NARC) Islamabad, Pakistan.

\subsection{Surface Sterilization \& Priming of Wheat Seeds}

Seeds of all four wheat varieties were immersed in a $10 \%$ sodium hypochlorite solution for 10 min to ensure surface sterility [9]. Then all seeds were rinsed thoroughly with distilled water and hand dried lightly using blotting paper. After surface sterilization imbibition of seeds were done by immersing seeds in distilled water for 6 hr at $25^{\circ} \mathrm{C}$ to get imbibed seeds. Other seeds were used as non-imbibed for further treatment.

\subsection{Treatment of Imbibed \& Non-Imbibed Seeds with Plant Derived Aerosol Smoke}

The imbibed and non-imbibed seeds of wheat were treated with plant derived aerosol smoke for about $1 \mathrm{hr}$ to check its effect on germination and post germination expression of wheat seeds. The plant derived smoke was used in aerosol form rather than as dissolved in water such as in the form of smoke water.

\subsection{Germination Assay}

Germination assay was done separately for both imbibed \& non-imbibed seeds of wheat varieties. One piece of filter paper was put into each Petri dish, and $5 \mathrm{ml}$ of distilled water was added. Treated seeds were then transferred onto the filter paper, in separate Petri dishes. Petri dishes were covered and sealed with tape, and placed in an incubator at $22^{\circ} \mathrm{C} \pm 4^{\circ} \mathrm{C}$. Germination counts were taken on a daily basis for 10 days. After 10 days root $\&$ shoot length was measured. Then, seed germination percentage, germination index, seedling vigor index was calculated, and seedling root and shoot length was also measured. Germination index was calculated using formula designed by ISTA [10], and seedling vigor index was calculated by using equation designed by Abdulbaki and Anderson [11]. 


$$
\begin{gathered}
\text { Germination \% age }=\frac{\text { Total seeds germinated } \times 100}{\text { Total no of seeds planted }} \\
\text { Germination Index }=\frac{\text { No of seedlings emerged on day }(\mathrm{n})}{\text { Days after planting }(\mathrm{d})}
\end{gathered}
$$

Seedling Vigor Index $=$ seedling length $(\mathrm{mm}) \times$ germination $\%$ age .

\subsection{Statistical Analysis}

Each treatment was conducted with three replicates, and the results were presented as mean standard deviation. The statistical analysis of experimental data utilized the Student's $t$-test. Each of the experimental values was compared to corresponding control.

\section{Results and Discussions}

Non-imbibed and imbibed seeds of wheat varieties were treated with plant derived smoke for about one hour and results for germination and post germination response were studied and recorded in Table 1. Both non-imbibed and imbibed wheat seeds indicate variability in germination percentage, germination index, seedling vigor index and root shoot length in response to plant derived smoke treatment. Plant derived smoke have been shown enhancing seed germination, seedling growth and vigor of a wide range of agricultural and horticultural crops [5]-[8]. Smoke stimulated seed germination has only been rarely reported among the Poaceae [12]-[15]. In wheat the bioactivity of plant derived smoke was first identified by Pepperman and Cutler [16] who conducted bioassays on wheat coleoptiles.

\subsection{Effect of Plant Derived Smoke on Seed Germination Percentage}

Effect of plant derived smoke on germination response of non-imbibed and imbibed seeds of different wheat verities are shown in Figure 1 \& Figure 2. Non-imbibed seeds treated with plant derived smoke showed best germination response as compared to imbibed seeds where germination response was very poor in all varieties. Germination percentage also varied from variety to variety. Maximum germination was recorded in Pak-13 (98 \pm 0.6), Gla-13 (95 \pm 0.6$)$ and in NARC-11 (92 \pm 2.31$)$ where rate of germination was increased upto $3.3 \%, 3 \%$ and $4 \%$ as compared to their corresponding control. Plant derived smoke stimulate and promote germination response as it increase seed sensitivity to endogenous $\mathrm{GA}_{4}$ [6] [17]-[19] and therefore enhance seed germination. Reduction in germination response was noticed in Aas-11 (88.3 \pm 10.2$)$ where both non-imbibed and imbibed seeds treated

Table 1. Overall view of plant derived smoke on germination \& post germination response of wheat.

\begin{tabular}{ccccccc}
\hline Variety & Treatments & $\begin{array}{c}\text { Germination } \\
\text { \%age }\end{array}$ & $\begin{array}{c}\text { Germination } \\
\text { index }\end{array}$ & $\begin{array}{c}\text { Seedling } \\
\text { vigor index }\end{array}$ & $\begin{array}{c}\text { Root } \\
\text { length } \mathbf{( c m )}\end{array}$ & $\begin{array}{c}\text { Shoot } \\
\text { length } \mathbf{( c m})\end{array}$ \\
\hline \multirow{2}{*}{ NARC-11 } & Control & $88 \pm 1.15$ & $17.6 \pm 0.2$ & $17,808.7 \pm 78$ & $9.8 \pm 1.9$ & $10.5 \pm 0.9$ \\
& N.I* seeds & $92 \pm 2.31$ & $18.4 \pm 0.5$ & $19,829.3 \pm 58$ & $9.7 \pm 3.3$ & $11.9 \pm 1.5$ \\
& Imbibed seeds & $75.3 \pm 12.3$ & $15.1 \pm 2.5$ & $14,127.3 \pm 22$ & $8.7 \pm 1.2$ & $10.2 \pm 0.9$ \\
& & & & & \\
Aas-11 & Control & $91 \pm 0.6$ & $18.2 \pm 0.1$ & $20,080 \pm 36$ & $10.4 \pm 2.8$ & $11.7 \pm 1.2$ \\
& N.I seeds & $88.3 \pm 10.2$ & $17.6 \pm 2.1$ & $20,816.7 \pm 34$ & $10.6 \pm 1.3$ & $12.9 \pm 1.5$ \\
& Imbibed seeds & $34.7 \pm 30.8$ & $6.9 \pm 6.2$ & $5112 \pm 46$ & $4.3 \pm 1.9$ & $5.5 \pm 2.3$ \\
& & & & & \\
Pak-13 & Control & $94.7 \pm 3.5$ & $18.9 \pm 0.7$ & $23,053.3+35$ & $12.5 \pm 3.3$ & $12.2 \pm 1.5$ \\
& N.I seeds & $98 \pm 0.6$ & $19.6 \pm 0.1$ & $24,084 \pm 48$ & $13.1 \pm 2.7$ & $12.2 \pm 1.7$ \\
& Imbibed seeds & $68.3 \pm 20.8$ & $13.7 \pm 4.2$ & $12,773.7 \pm 51$ & $7.4 \pm 2.9$ & $10.3 \pm 1.7$ \\
& & & & & \\
Gla-13 & Control & $92 \pm 2.3$ & $18.4 \pm 0.5$ & $19,626.7 \pm 32$ & $8.9 \pm 1.9$ & $12.5 \pm 1.9$ \\
& N.I seeds & $95 \pm 0.6$ & $19 \pm 0.1$ & $21,092.7 \pm 35$ & $9.9 \pm 2.1$ & $12.3 \pm 1.8$ \\
& Imbibed seeds & $57.3 \pm 25.4$ & $11.5 \pm 5.1$ & $9093.3 \pm 343$ & $6.0 \pm 0.5$ & $11.3 \pm 1.5$ \\
\hline
\end{tabular}

*N.I seeds $=$ Non-imbibed seeds. 


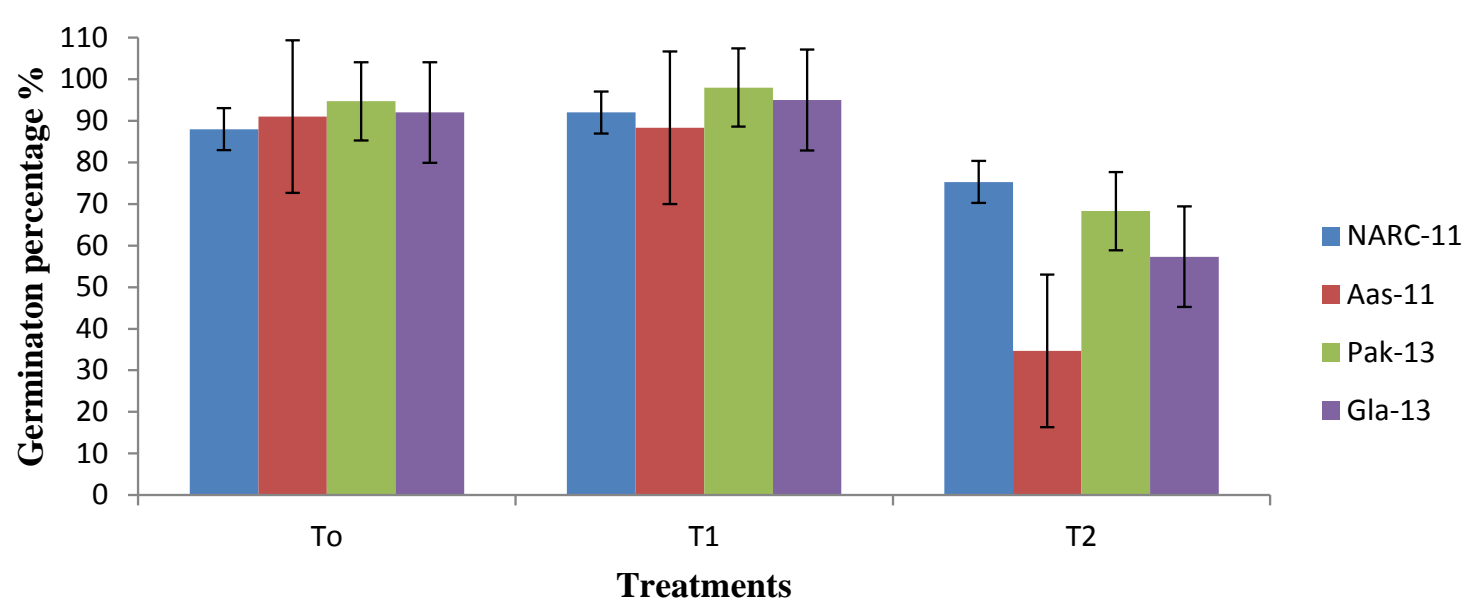

Figure 1. Effect of plant derived aerosol smoke on wheat seed germination percentage $($ To = control, $\mathrm{T} 1=$ Non-imbibed seeds treated with plant derived aerosol smoke, T2 = Imbibed seeds treated with plant derived aerosol smoke).
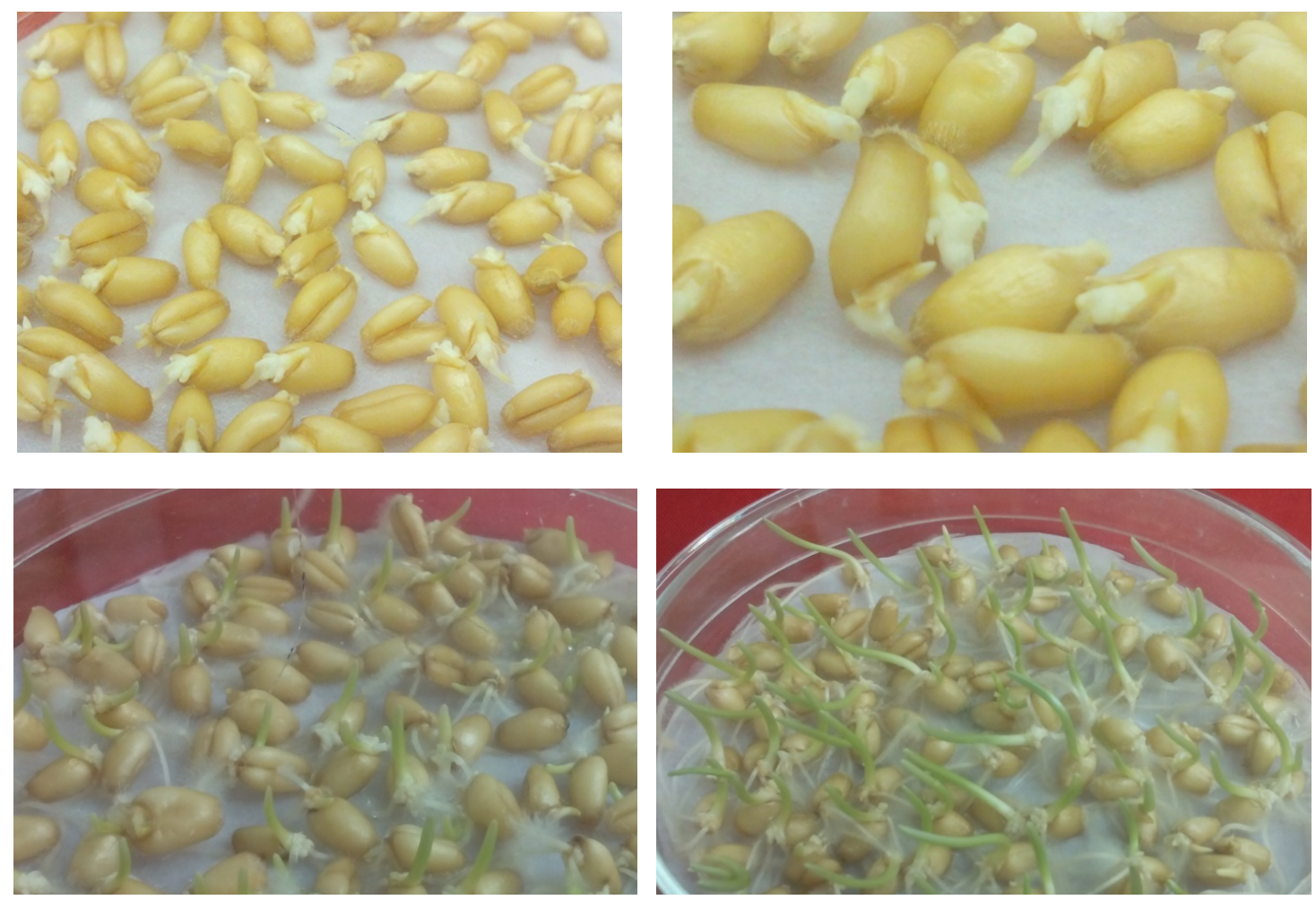

Figure 2. Germination stages of wheat seeds in response to treatment with plant derived aerosol smoke.

with plant derived smoke failed to show pronounced effect. Sometimes plant derived smoke can negatively or positively affect germination [17] [20] [21].

\subsection{Effect of Plant Derived Smoke on Seed Germination Index and Seedling Vigor Index}

Smoke, however, not only influences germination but importantly it also stimulates seedling vigor (post-germinative growth) [12] [22]. In present investigation there were significant difference was noticed in germination index and seedling vigor index among different wheat varieties in response to plant derived smoke (Figure 3 \& Figure 4). Non-imbibed seeds of Pak-13, Gla-13 and NARC-11 showed considerable increase in germination index and seedling vigor index as compared to imbibed seeds while Aas-11 show reduction in both non-imbibed 

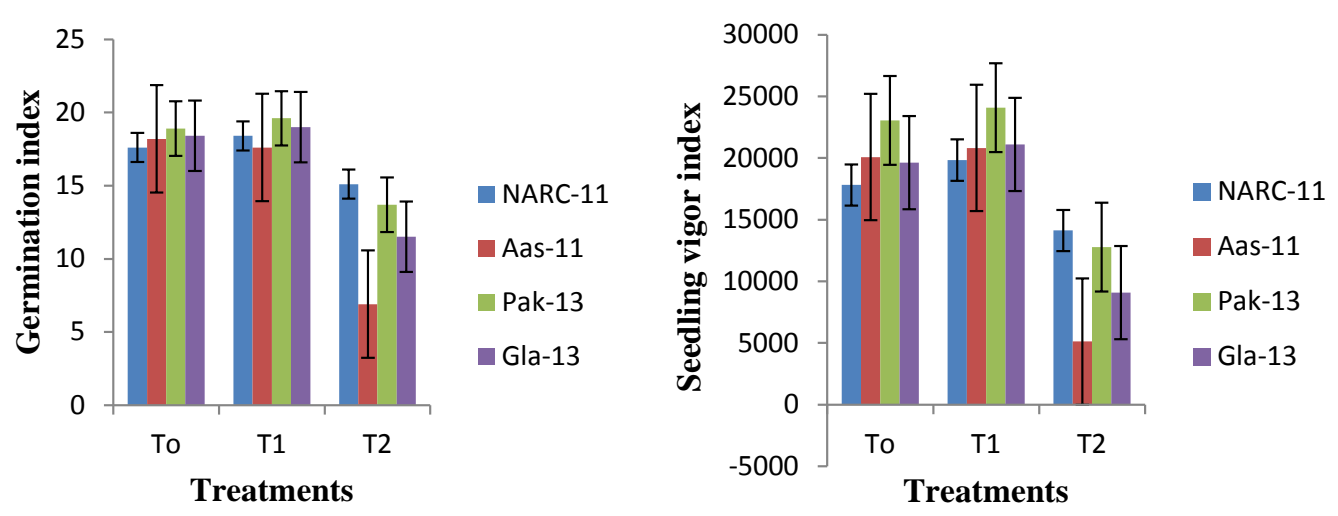

Figure 3. Effect of plant derived smoke on Germination index \& Seedling vigor index $($ To $=$ control, T1 = Non imbibed seeds treated with plant derived smoke, T2 = Imbibed seeds treated with plant derived smoke).
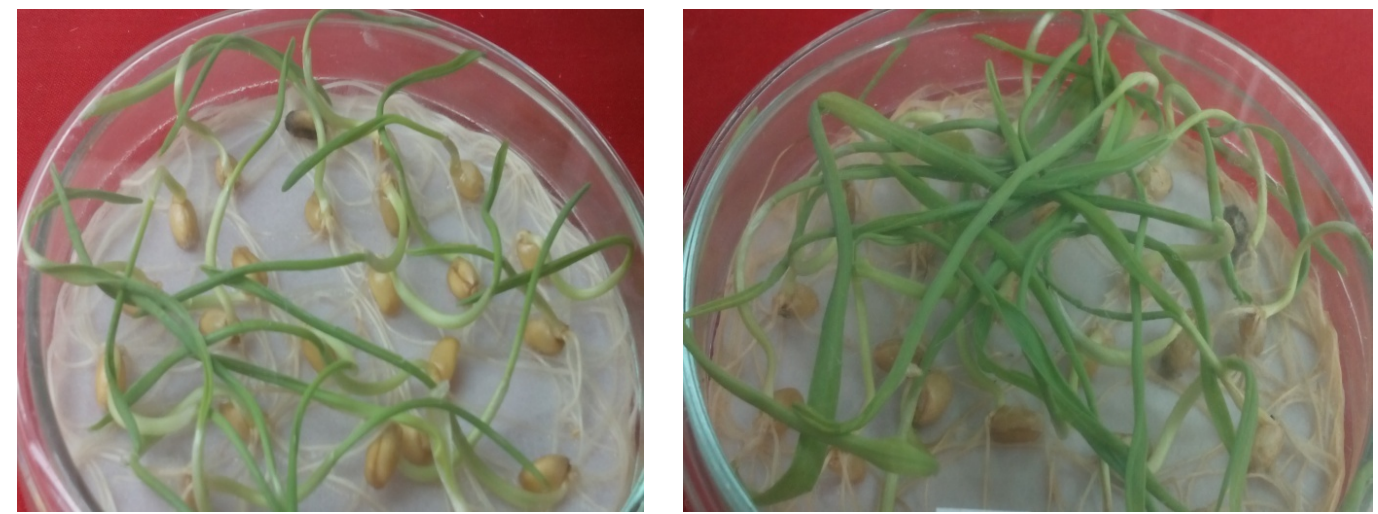

Figure 4. Seedling stage of wheat in response to treatment with plant derived smoke.

and imbibed seeds being treated with plant derived smoke. Baxter et al. [12] reported that the seedlings of Themeda triandra from smoke-treated seeds grew more vigorously without any abnormalities than untreated seeds. A similar effect was observed in species of Ericaceae and Asteraceae family [23] and in commercial maize (Zea mays) [7]. Plant derived smoke has a positive effect on seedling vigor [24] and favor high seedling establishment and may increase species diversity [25]-[27].

\subsection{Effect of Plant Derived Smoke on Root Shoot Length}

To examine the effect of plant derived smoke on root shoot growth, both non-imbibed \& imbibed seeds were incubated on Petri dishes with $5 \mathrm{ml}$ distilled water after being treated with plant derived smoke for one hour time duration. Increase in root growth was seen in seedlings emerged from non-imbibed seeds treated with plant derived smoke as compared to imbibed seed where reduction in root length was noticed with respect to control (Figure 5 \& Figure 6). Maximum root length was recorded in non-imbibed seeds of Pak-13 (13.1 mm), Aas-11 (10.6 mm) and Gla-13 (9.9 mm) where as imbibed seeds of all varieties did not show significant increase in root length. Number of studies have been reported a positive influence of plant derived smoke treatments on seedling growth and development of several crop plants, including celery [28], lettuce [29], okra [6], tomato [30], onion [31], aubergine [32], Brassica tornefortii [33], pepper (Capsicum annuum L.) and salvia species [8].

Shoot growth was also observed with the same treatment as applied for root growth to examine the effect of plant derived smoke on wheat growth. Non-imbibed seeds treated with plant derived smoke exhibited significant increase in shoot length while imbibed seeds showed comparable results in shoot length as compared to seedlings not treated with plant derived smoke. Remarkable increase in shoot length was observed in non-imbibed seeds of NARC-11 (12 mm) and Aas-11 (12.9 mm) and in imbibed seeds of NARC-11 (10.2 mm) and Gla-13 (11.3 mm) varieties after treatment with plant derived smoke. Zhou et al. [34] reported that plant derived smoke improves shoot growth in Isatis indigotica seedling. Seeds treated with plant derived smoke grow faster and has increased 

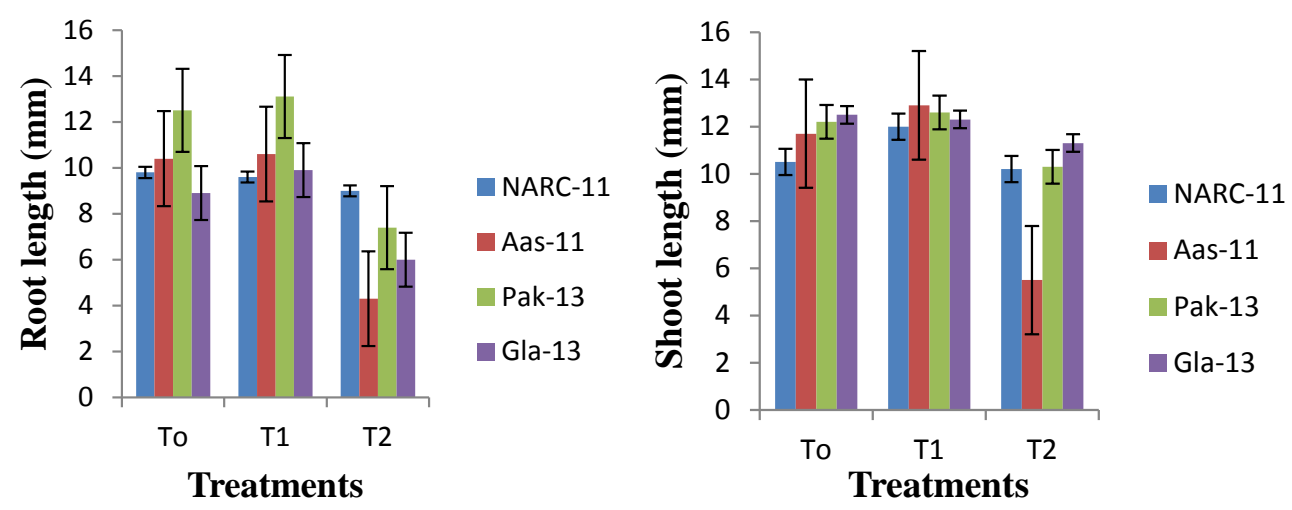

Figure 5. Effect of plant derived smoke on Root and Shoot length $($ To $=$ control, $\mathrm{T} 1=$ Non imbibed seeds treated with plant derived smoke, $\mathrm{T} 2$ = Imbibed seeds treated with plant derived smoke).
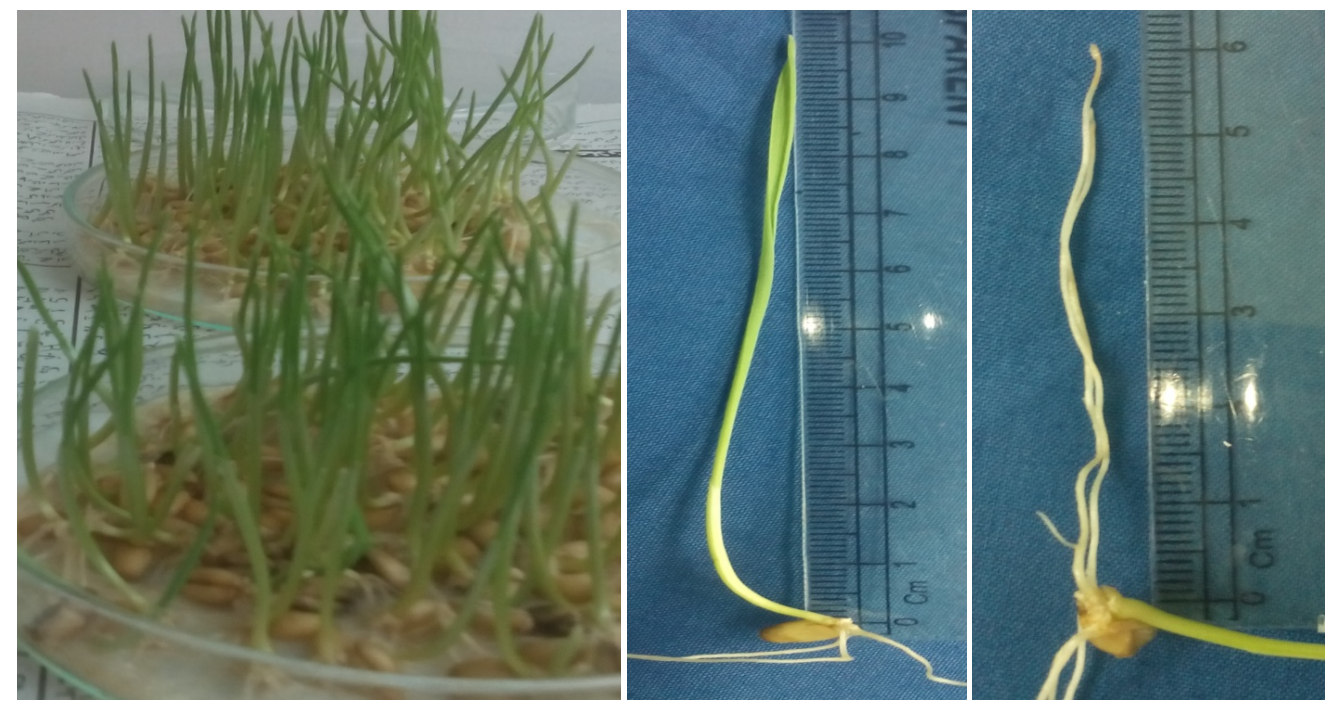

Figure 6. Maturation of seedlings and development of shoot \& root in wheat in response to treatment with plant derived smoke.

vigor and fresh weight [22] [34]-[36]. Plant derived smoke treatments have great potential for use in horticulture and agriculture [24] [37] [38].

\section{Conclusion}

It is concluded from present work that plant derived smoke significantly increased seed germination, seedling vigor, and root shoot growth. Furthermore it was reported for the first time in wheat that non-imbibed seeds treated with plant derived smoke for one hour duration showed positive response in germination, seedling vigor and root shoot growth as compared to imbibed seeds where results were less significant.

\section{References}

[1] FAO (2013) FAO Land and Plant Nutrition Management Service. http://www.fao.org

[2] Akhtar, S. and Ashgar, A. (2011) Mineral Fortification of Whole Wheat Flour: An Overview. In: Preedy, V.R., Watson, R.R. and Patel, V.B., Eds, Flour and Bread Sand Their Fortification in Health and Disease Prevention, Academic Press, San Diego, 263-271. http://dx.doi.org/10.1016/B978-0-12-380886-8.10024-8

[3] De Lange, J.H. and Boucher, C. (1990) Aut-Ecological Studies on Audouinia capitata (Bruniaceae). Plant-Derived Smoke as a Seed Germination Cue. South African Journal of Biotechnology, 56, 700-703.

[4] Van Staden, J., Brown, N.A.C., Jager, A.K. and Johnson, T.A. (2000) Smoke as a Germination Cue. Plant Species Bi- 
ology, 15, 167-178. http://dx.doi.org/10.1046/j.1442-1984.2000.00037.x

[5] Brown, N.A.C. and Van Staden, J. (1999) Plant-Derived Smoke: An Effective Seed Pre-Soaking Treatment for Wild Flower Species and with Potential for Horticultural and Vegetable Crops. Seed Science Technology, 26, 669-673.

[6] Kulkarni, M.G., Ascough, G.D. and Van Staden, J. (2007) Effects of Foliar Applications of Smoke-Water and a Smoke-Isolated Butenolide on Seedling Growth of Okra and Tomato. Horticulture Science, 42, 179-182.

[7] Sparg, S.G., Kulkarni, M.G. and Van Staden, J. (2006) Aerosol-Smoke and Smoke-Water Stimulation of Seedling Vigor of a Commercial Maize Cultivar. Crop Science, 46, 1336-1340. http://dx.doi.org/10.2135/cropsci2005.07-0324

[8] Demir, I., Ozuaydin, F., Yasar, J. and Van Staden, J. (2012) Effect of Smoke-Derived Butenolide Priming Treatment on Pepper and Salvia Seeds in Relation to Transplant Quality and Catalase Activity. South African Journal of Biotechnology, 78, 83-87. http://dx.doi.org/10.1016/j.sajb.2011.05.009

[9] U.S. Environmental Protection Agency (1996) Ecological Effects Test Guidelines (OPPTS850.4200): Seed Germination/Root Elongation Toxicity Test.

[10] ISTA (2005) International Rules for Seed Testing. International Seed Testing Association, Zurich, Switzerland.

[11] Abdul-Baki, A. and Anderson, J.D. (1973) Vigor Determination in Soybean Seed by Multiple Criteria. Crop Science, 13, 630-633. http://dx.doi.org/10.2135/cropsci1973.0011183X001300060013x

[12] Baxter, B.J.M. and Van Staden, J. (1994) Plant-Derived Smoke: An Effective Seed Pre-Treatment. Plant Growth Regulation, 14, 279-282. http://dx.doi.org/10.1007/BF00024804

[13] Jefferson, L., Pennacchio, M., Havens, K.,Forsberg, B., Sollenberger, D. and Ault, J. (2008) Ex. situ Germination Responses of Midwestern USA Prairie Species to Plant-Derived Smoke. American Midland Naturalist, 159, 251-256.

[14] Schwilk, D.W. and N. Zavala, N. (2012) Germination Response of Grassland Species to Plant-Derived Smoke. Journal of Arid Environment, 79, 111-115. http://dx.doi.org/10.1016/j.jaridenv.2011.12.002

[15] Ghebrehiwot, H., Kulkarni, M., Bairuand, M. and Van Staden, J. (2013) Plant-Derived Aerosol-Smoke and Smoke Solutions Influence Agronomic Performance of a Traditional Cereal Crop, tef. Experimental Agriculture, 49, $244-255$. http://dx.doi.org/10.1017/S0014479712001068

[16] Pepperman, A.B. and Cutler, H.G. (1991) Plant-Growth-Inhibiting Properties of Some 5-Alkoxy-3-methyl-2(5H)-furanones Related to Strigol. ACS Symposium Series, 443, 278-287. http://dx.doi.org/10.1021/bk-1991-0443.ch023

[17] Schwachtje, J. and Baldwin, I.T. (2004) Smoke Exposure Alters Endogenous Gibberellin and Abscisic Acid Pools and Gibberellin Sensitivity While Eliciting Germination in the Post-Fire Annual, Nicotiana attenuata. Seed Science Research, 14, 51-60. http://dx.doi.org/10.1079/SSR2003154

[18] Chiwocha, S.D., Dixon, K.W., Flematti, G.R., Ghisalberti, E.L., Merritt, D.J., Nelson, D.C., Riseborough, J.A.M., Smith, S.M. and Stevens, J.C. (2009) Karrikins: A New Family of Plant Growth Regulators in Smoke. Plant Science, 177, 252-256. http://dx.doi.org/10.1016/j.plantsci.2009.06.007

[19] Light, M.E., Burger, B.V., Staerk, D., Kohout, L. and VanStaden, J. (2010) Butenolides from Plant-Derived Smoke: Natural Plant-Growth Regulators with Antagonistic Actions on Seed Germination. Journal of Natural Products, 73, 267-269. http://dx.doi.org/10.1021/np900630w

[20] Preston, C.A., Becker, R. and Baldwin, I.T. (2004) Is “NO” News Good News? Nitrogen Oxides Are Not Components of Smoke That Elicits Germination in Two Smoke-Stimulated Species, Nicotiana attenuata and Emmenanthependuli flora. Seed Science Research, 14, 73-79. http://dx.doi.org/10.1079/SSR2003156

[21] Thomas, P.B., Morris, E.C. and Auld, T.D. (2007) Response Surfaces for the Combined Effects of Heat Shock and Smoke on Germination of 16 Species Forming Soil Seed Banks in South-East Australia. Australian Ecology, 32, 605-616. http://dx.doi.org/10.1111/j.1442-9993.2007.01730.x

[22] Sparg, S.G., Kulkarni, M.G, Light, M.E. and Van Staden, J. (2005) Improving Seedling Vigor of Indigenous Medicinal Plants with Smoke. Bioresearch Technology, 96, 1323-1330. http://dx.doi.org/10.1016/j.biortech.2004.11.015

[23] Brown, N.A.C. (1993) Promotion of Germination of Fynbos Seeds by Plant Derived Smoke. New Phytology, 123, 575-583. http://dx.doi.org/10.1111/j.1469-8137.1993.tb03770.x

[24] Light, M.E., Daws, M.I. and Van Staden, J. (2009) Smoke-Derived Butenolide: Towards Understanding Its Biological Effects. South Africa Journal of Botany, 75, 1-7. http://dx.doi.org/10.1016/j.sajb.2008.10.004

[25] Read, T.R., Bellairs, S.M., Mulligan, D.R. and Lamb, D. (2000) Smoke and Heat Effect on Soil Seed Bank Germination for the Re-Establishment of a Native Forest Community in New South Wales. Australian Ecology, 25, 48. http://dx.doi.org/10.1046/j.1442-9993.2000.01031.x

[26] Enright, N.J. and Kintrup, A. (2001) Effects of Smoke, Heat and Charred Wood on the Germination of Dormant Soil-Stored Seeds from a Eucalyptus baxteri Heat Wood Land in Victoria, SE Australia. Australian Ecology, 26, 132-141. http://dx.doi.org/10.1046/j.1442-9993.2001.01096.x 
[27] Wills, T.J. and Read, J. (2002) Effects of Heat and Smoke on Germination of Soil-Stored Seed in South-Eastern Australia Sand Heath Land. Australian Journal of Botany, 50, 197-206. http://dx.doi.org/10.1071/BT01017

[28] Thomas, T.H. and Van Staden, J. (1995) Dormancy Break of Celery (Apium graveolens L.) Seeds by Plant-Derived Smoke Extract. Plant Growth Regulation, 17, 195-198. http://dx.doi.org/10.1007/BF00024725

[29] Strydom, A., Jäger, A.K. and Van Staden, J. (1996) Effect of Plant-Derived Smoke Extract, N 6-Benzyladenine and Gibberellic Acid on the Thermodormancy of Lettuce Seeds. Plant Growth Regulation, 19, 97-100. http://dx.doi.org/10.1007/BF00024574

[30] Kulkarni, M.G., Ascough, G.D. and Van Staden, J. (2008) Smoke-Water and a Smoke-Isolated Butenolide Improve Growth and Yield of Tomatoes under Greenhouse Conditions. Horticulture Technology, 18, 449-454.

[31] Kulkarni, M.G., Ascough, G.D., Verschaeve, L., Baeten, K., Arruda, M.P. and Van Staden, J. (2010) Effect of SmokeWater and a Smoke-Isolated Butenolide on the Growth and Gene Toxicity of Commercial Onion. Horticultural Science, 124, 434-439. http://dx.doi.org/10.1016/j.scienta.2010.02.005

[32] Demir, I., Light, M.E., Van Staden, J., Kenanoglu, B.B. and Celikkol, T. (2009) Improving Seedling Growth of Unaged and Aged Aubergine Seeds with Smoke Derived Butenolide. Seed Science Technology, 37, 255-260. http://dx.doi.org/10.15258/sst.2009.37.1.31

[33] Long, R.L., Williams, K., Griffiths, E.M., Flematti, G.R., Merritt, D.J., Stevens, J.C., Turner, S.R., Powles, S.B. and Dixon, K.W. (2010) Prior hydration of Brassica tournefortii Seeds Reduces the Stimulatory Effect of Karrikinolide on Germination and Increases Seed Sensitivity to Abscisic Acid. Annals of Botany, 105, 1063-1070. http://dx.doi.org/10.1093/aob/mcq061

[34] Zhou, J., Van Staden, J., Guo, L.P. and Huang, L.Q. (2011) Smoke-Water Improves Shoot Growth and Indigo Accumulation in Shoots of Isatis indigotica Seedlings. South African Journal of Biotechnology, 77, 787-789. http://dx.doi.org/10.1016/j.sajb.2011.02.004

[35] Jain, N., Kulkarni, M.G. and Van Staden, J. (2006) Abutenolide Isolated from Smoke, Can Overcome the Detrimental Effects of Extreme Temperatures during Tomato Seed Germination. Plant Growth Regulation, 49, 263-267. http://dx.doi.org/10.1007/s10725-006-9136-0

[36] Daws, M.I., Davies, J., Pritchard, H.W., Brown, N.A.C. and Van Staden, J. (2007) Butenolide from Plant-Derived Smoke Enhances Germination and Seedling Growth of Arable Weed Species. Plant Growth Regulation, 51, 73-82. http://dx.doi.org/10.1007/s10725-006-9149-8

[37] Light, M.E. and Van Staden, J. (2004) The Potential of Smoke in Seed Technology. South African Journal of Biotechnology, 70, 97-101. http://dx.doi.org/10.1016/S0254-6299(15)30311-2

[38] Boucher, C. and Meets, M. (2004) Determination of the Relative Activity of Aqueous Plant-Derived Smoke Solution Used in Seed Germination. South African Journal of Biotechnology, 70, 313-318. http://dx.doi.org/10.1016/S0254-6299(15)30252-0 